\title{
Combination of Calotropis gigantea Radix Extract and Artemisin as an Antimalarial Agent Against Plasmodium berghei
}

\author{
${ }^{1}$ Roihatul Muti'ah, ${ }^{2}$ Elok Kamilah Hayati, ${ }^{3}$ Asnal Fatati \\ ${ }^{1}$ Department of Pharmacy, Faculty of Science and Technology, Maulana Malik Ibrahim State \\ Islamic University of Malang, Indonesia \\ ${ }^{2}$ Department of Chemistry, Faculty of Science and Technology, Maulana Malik Ibrahim State \\ Islamic University of Malang, Indonesia \\ *Email : roihatulmutiah@gmail.com
}

\begin{abstract}
Calotropis gigantea radix is one of plant which has bioactive component as antimalarial.The purpose of this research are to know antimalarial activity from combination of Calotropis gigantea radix extract and artemisin. The research consist of extraction of Calotropis gigantea radix was done with extraction maseration method. Extraction was performed by maseration with $80 \%$ ethanol solvent. Concentrated extract was in vivo antimalarial tested to animal model. Mice were peritoneal infected with $10^{6}$ Plasmodium berghei ANKA and divided into 5 treatment groups: negative control; positive control (artemisin of dose $4 \mathrm{mg} / \mathrm{kgBW}$ ); combination of artemisin(1/4 dose of artemisin standar) and Calotropis giganteain 3 doses: $0,1 \mathrm{mg} / \mathrm{KgBW} ; 1 \mathrm{mg} / \mathrm{KgBW}$ and $10 \mathrm{mg} / \mathrm{KgBW}$. Data of inhibition was analyzed using SPSS program with Two Way ANOVA Test dan continued with Tukey Test.

The result shows that combination of Calotropis gigantea radix extract and artemisin with dose $10 \mathrm{mg} / \mathrm{KgBB}$ has higher antimalarial activity than control positive (artemisin). The value of parasite inhibition is $55,2 \%$ for dose $0.1 \mathrm{mg} / \mathrm{KgBW} ; 72,8 \%$ for dose $1 \mathrm{mg} / \mathrm{KgBW} ; 87,3 \%$ for dose $10 \mathrm{mg} / \mathrm{KgBW}$ and $56,06 \mathrm{mg} / \mathrm{KgBW}$ for control positive (artemisin). The phytochemical compounds in $80 \%$ ethanol solvent extract are tannins and steroids.
\end{abstract}

Keywords: Calotropis gigantea, antimalaria, combination, artemisin, Plasmodium berghei

\section{INTRODUCTION}

Malaria is a disease which is pretty much contracted in Indonesia.This is because Indonesia is a tropical region. Malaria is wide spread in tropical and sub tropical regions including part of the American, Asia and Africa [9]. Malaria is an infectious and parasitic diseases plague that affects many people in tropical and subtropical regions, especially in swampy areas. The infected of malaria often peaks during the rainy season [6].

Malaria parasite are transmited by female anopheles mosquitoes bite.The types of protozoa that found in malaria arethe types of Plasmodium that are nested within the red blood cells. The parasites multiply within red blood cell causing symptoms that inlude anemia as well as other general symptoms such as fever, chills, flu and in severe cases coma and death. Treatment of malaria are resistantlately.The presence of resistant led to increased the mortality rates. There have reports of treatment resistance of malaria(chloroquine, sulfadoxine-pyrimethamine and quinine) that occurring in over $25 \%$ of provinces in Indonesia. Prevention of the development of this resistance can be done with a combination of two or more antimalarial drugs.

WHO (2000), have suggested thatArtemesine Based Combination (ACT) as a drug in the treatment of malaria. Artemisin is a sesquiterpene lactone that isolated from the plant 
Artemisia annua. Combination antimalarial therapy has good the activity up to $100 \%$ during the 3 days of treatment.

Antimalarials such as artemisinin combination with extracts of natural materials are still rare, but there are a lot of natural materials that a source of antimalarial.Taking preventif drugs (orthodox and traditional drugs) can reduce risk of infection [4].Antimalarial combination therapy with artemisin also been carried out by [2] that there is a malarial activity of the combination therapy of artesunate and $80 \%$ ethanol extract of the stem bark Cempedak (Artocarpus Champeden Spreng.). In these studies obtained that the highest percent inhibition of parasite from the extract of Artocarpus Champeden is combination extract $100 \mathrm{mg} / \mathrm{KgBW}$ dan artesunat $36,4 \mathrm{mg} / \mathrm{KgBW}$.

Mudi and bukar (2011), found that there antimalarial activity of the leaf extract Calotropis procera.Calatropis gigantea as a genus of plants with Calatropis procera also indicated as having antimalarial activity. This study aims to determine the effect of synergistic combination of $80 \%$ ethanol extract of Calatropis gigantea radix and artemisin as antimalarials and to determine the active compounds that contained in the $80 \%$ ethanol extract of Calatropis gigantearadix based of reagent test and reinforced by Thin Layer Chromatography (TLC) test.

\section{MATERIALS AND METHODS Sample Preparation}

Radixs of Calotropis gigantea were collected at Pasuruan town, Indonesia on January 6, 2014. The radixs were identified at the Departement of Biological Science, University of Malik Ibrahim Malang. The radixs were cleaned and drined. The dried sample was pulverized until 60 mesh.

\section{Extractionof Maseration}

The air-dried sample (100 gr) was extracted using Ethanol 80\% (250 mL) until 24 hours and filtrated. The residue obtained after extraction was reextractedwith Ethanol 80\% (150 and 100 $\mathrm{mL}$ ) or until the filtrat was transparent. The extract were drained and concentrated under reduce pressure using Rotary Evaporator $\left(70-75^{\circ} \mathrm{C}\right)$. The ethanol extract was allowed to dry and its contstant weight was recorded.

\section{Chemical Analysis}

Plant extract were phytochemically screened using standard techniques for the qualitative detection of Flavonoid, Tannins, Alkaloid,Triterpenoid, Steroid and Saponins. [3] and with TLC (Thin Layer Chromatography) methode.

\section{Antimalarial Activity In Vivo of the Extract on Plasmodium berghei}

Antimalarial activity in vivo was tested to animal model. Mice were peritoneal infected with $10^{6}$ Plasmodium berghei ANKA and divided into 5 treatment groups: negative controll (CMC $\mathrm{Na} 1 \%$ ); positive control (artemisin of dose $4 \mathrm{mg} / \mathrm{kgBW}$ ); combination of artemisin(1/4 dose of artemisin standar) and Calotropis giganteain 3 doses: $0,1 \mathrm{mg} / \mathrm{KgBW} ; 1 \mathrm{mg} / \mathrm{KgBWand} 10$ $\mathrm{mg} / \mathrm{KgBW}$. Each group has 6 mice. The parasitemia degree was determined by tail's blood smear of mice until 4 days.

\section{Analysis of Data}

The data was described with table and graph.The dose effectivity of 50\% (ED50) was determined by percent of probit analyze from parasite inhibition during 4 days and that showed by linear regression analyze with Microsoft Office Excel program. The data of 
inhibition was analyzed using SPSS program with Two Way ANOVA Test dan continued with Tukey Test.

\section{RESULT AND DISCUSSION \\ Sample Preparation}

Drying sample were meant to reduce the water content, stop the enzymatic reaction, and prevent the growth of mold, so it can be kept longer (preservation) and the chemical composition does not change easily. The dried sample was pulverized until 60 mesh.Pulverizing can facilitate the extraction process. The smaller of surface area are make the greater interaction between extract and solvent, so the extraction proces is more effective. The sample with high smoothing powder is also have high probability of damage cells, so it make easier to capture the content material by the solvent.

\section{Extraction of Maseration}

The powder samples were weighed as much as $50 \mathrm{~g}$ with 2 replications, and its was extracted by ethanol $80 \%$ until 24 hours. The maseration proces was supported by shaker until 3 hours $(120 \mathrm{rpm})$. The stirring of maceration process is intended to improve the efficiency of solvent saturation, so it will happen faster and more homogeneous extract obtained.In this proces, the solvent will break through the cell of sample, so the active components will be dissolved. The characteristic of active components is same as the characteristic of solvent. It was appropriate by the law of "like dissolve like" that is the only polar compounds that are soluble in polar solvents and non-polar compound is only soluble in non-polar solvents.

The extract were drained and concentrated under reduce pressure using Rotary Evaporator $\left(70-75^{\circ} \mathrm{C} ; \pm 800 \mathrm{hPa} ; 5 \mathrm{rpm}\right)$.

Table 1. Results of extraction maceration (Calotropis gigantea)

\begin{tabular}{|c|c|c|c|}
\hline Solvent & Discoloration filtrate & $\begin{array}{c}\text { concentrated } \\
\text { extract }\end{array}$ & $\mathbf{\%}(\mathbf{b} / \mathbf{b})$ \\
\hline Ethanol & Dark green into pale green & Hijau tua & 16,4718 \\
\hline
\end{tabular}

\section{Chemical Analysis}

\section{Phytochemicals Test with Reagent}

Phytochemical test was conducted to determine the content of the ethanol extract compounds in radix of Calotropis gigantea. The test was done by taking a sample of ethanol extract.Phytochemical test carried out on this class of compounds Flavonoids, Tannins, Alkaloids,Triterpenoids, Steroidsand Saponins.

Table 2. Test $80 \%$ ethanol extract of phytochemicals (Calotropis gigantea)

\begin{tabular}{|c|c|}
\hline Golongan senyawa & Ekstrak etanol 80\% \\
\hline Flavonoids & - \\
\hline Tannins & ++ \\
\hline Alkaloids & - \\
\hline Triterpenoids & - \\
\hline Steroids & ++ \\
\hline Saponins & - \\
\hline
\end{tabular}




\section{Phytochemicals Test withThin Layer Chromatography (TLC)}

The result of phytochemicals test with reagent are tannis and steroids. The verification content of these compounds reinforced with the identification using TLC. The resulting stain subsequently detected with appropriate reagents class compounds, then observed under UV light.

\section{Steroids}

The results of identification using TLC for group of steroid compounds in Calotropis gigantea using eluent hexane: acetone (3.5: 1.5) that showed by Figure 1. Reveny (2011), shows that the results of the TLC group of steroid compounds with Lieberman-Burchard reagent showed by the formation of a red purple.In the ethanol extract showed $\mathrm{Rf}$ between 0,05 to 0,6 with 7 stain. The $1^{\text {st }}$ and $2^{\text {nd }}$ stain showed a Greenish white, and the $3^{\text {rd }}-7^{\text {th }}$ stain showed a red purple.

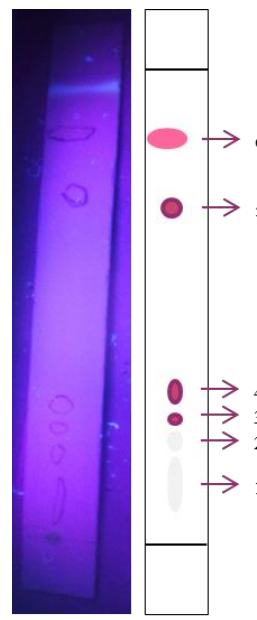

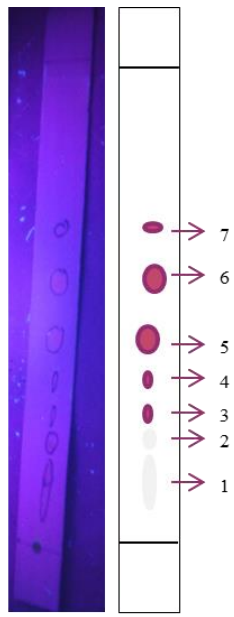

Fig 1. The results of the ethanol extract of steroid compounds TLC eluent hexane: acetone (3.5: 1.5), (1) Results spotting before sprayed detection reagents (366 UV lamp), (2) Results spotting after sprayed detection reagents (366 UV lamp)

Table 3. The results of steroid TLC with eluent hexane: acetone (3.5: 1.5)

\begin{tabular}{c|ccccc}
\hline $\mathrm{No}$ & $R f$ & $\begin{array}{c}\text { Color patches with } \\
\text { 366 nm UV light, } \\
\text { before given detector }\end{array}$ & Rf & $\begin{array}{c}\text { Color patches with 366 } \\
\text { nm UV light, after given } \\
\text { detector }\end{array}$ & $\begin{array}{c}\text { Alleged } \\
\text { compound }\end{array}$ \\
\hline 1 & 0,05 & Grayish-white & 0,05 & Greenishwhite & - \\
2 & 0,16 & Grayish-white & 0,16 & Greenish white & - \\
3 & 0,22 & Red purple & 0,22 & Red purple & Steroid \\
4 & 0,26 & Red purple & 0,26 & Red purple & Steroid \\
5 & 0,76 & Red purple & 0,33 & Red purple & Steroid \\
6 & 0,86 & Pink & 0,38 & Red purple & Steroid \\
7 & & & 0,49 & Red purple & Steroid \\
8 & & & 0,6 & Red purple & Steroid \\
\hline
\end{tabular}

\section{Tannins}

The results of identification using TLC for group of tannins compounds in Calotropis gigantea using eluent chloroform : methanol : water $(7: 3: 0,4)$ that showed by Figure 2 . Fitriyani et al (2011), shows that the results of the TLC group of tannins compounds with 
$\mathrm{FeCl}_{3}$ reagent showed by the formation of a blackish purple.

Table 4. The results of tannins TLC with eluent chloroform : methanol : water $(7: 3: 0,4)$

\begin{tabular}{c|ccccc}
\hline No & Rf & $\begin{array}{c}\text { Color patches with 366 } \\
\text { nm UV light, before } \\
\text { given detector }\end{array}$ & $R f$ & $\begin{array}{c}\text { Color patches with } \\
366 \text { nm UVlight, after } \\
\text { given detector }\end{array}$ & $\begin{array}{c}\text { Alleged } \\
\text { compound }\end{array}$ \\
\hline 1 & 0,62 & Red Purple & 0,41 & greenish white & - \\
2 & 0,78 & Grayish-white & 0,62 & Blackish purple & Tanin \\
3 & 0,85 & Blackish purple & 0,78 & Grayish-white & - \\
4 & & & 0,85 & Red Purple & - \\
5 & & & 0,87 & Cream & - \\
\hline
\end{tabular}

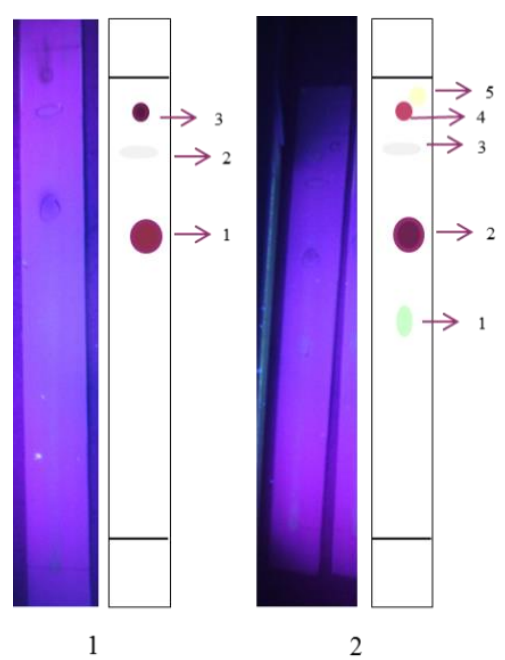

Fig 2. The results of the ethanol extract of tannins compounds TLC chloroform : methanol : water $(7: 3: 0,4),(1)$ Results spotting before sprayed detection reagents (366 UV lamp), (2)

Results spotting after sprayed detection reagents (366 UV lamp)

\section{Antimalarial Activity In Vivo of the Extract on Plasmodium berghei}

The test of antimalarial activity in vivo performed withanimal tests using male mice (Mus musculus ; Balb/C). Mice were peritoneal infected with $10^{6}$ Plasmodium berghei ANKA and divided into 5 treatment groups: negative control; positive control (artemisin of dose 4 $\mathrm{mg} / \mathrm{kgBW})$; combination of artemisin(1/4 dose of artemisin standar) and Calotropis giganteain 3 doses: $0,1 \mathrm{mg} / \mathrm{KgBW} ; 1 \mathrm{mg} / \mathrm{KgBW}$ and $10 \mathrm{mg} / \mathrm{KgBW}$.

Table 5. Parasitemia average degree of radix extract (Calotropis gigantea)

\begin{tabular}{l|ccccc}
\hline \multirow{2}{*}{ Treatment } & \multicolumn{5}{|c}{ Average degree of parasitemia(\%) \pm standard deviation } \\
\cline { 2 - 6 } & Day-0 & Day-1 & Day-2 & Day-3 & Day-4 \\
Control (-) & $2,9 \pm 0,76$ & $3,04 \pm 0,22$ & $3,4 \pm 0,33$ & $3,6 \pm 1,04$ & $3,86 \pm 0,33$ \\
Control (+) & $2,34 \pm 0,43$ & $2,22 \pm 0,43$ & $1,54 \pm 0,30$ & $1,38 \pm 0,22$ & $0,7 \pm 0,11$ \\
Dose 1 & $3,88 \pm 0,48$ & $2,34 \pm 0,33$ & $1,7 \pm 0,50$ & $1,44 \pm 0,35$ & $0,5 \pm 2,86$ \\
Dose 2 & $3,14 \pm 0,60$ & $2,12 \pm 0,85$ & $1,74 \pm 0,31$ & $1,9 \pm 0,51$ & $1,04 \pm 0,43$ \\
Dose 3 & $2,4 \pm 1,26$ & $2,32 \pm 0,39$ & $1,74 \pm 0,29$ & $1,2 \pm 0,10$ & $1,72 \pm 0,23$ \\
\hline
\end{tabular}


Therapy was done when the degree of parasitemia after infection reaches 1-5\%(it calculated as day 0).The degree of parasitemia on day 0 is aiming to prove all the mice are in the same range of degrees of parasitemia on day of treatment will be done.Therapy was given for 4 days, that use to know the profile of parasite growth after a given treatment.

The average degree of parasitaemia in all treatments on day 0 is equal to $2-3 \%$. Treatment of the negative control group showed the highest degree of parasitemia.The degree of parasitemia was obtained from a blood thinner dosage by counting the number of cells infected with Plasmodium bergheiin 1000 erythrocytes. The observation of blood smear Plasmodium berghei infected in the negative control (no treatment) are presented in Figure 3.

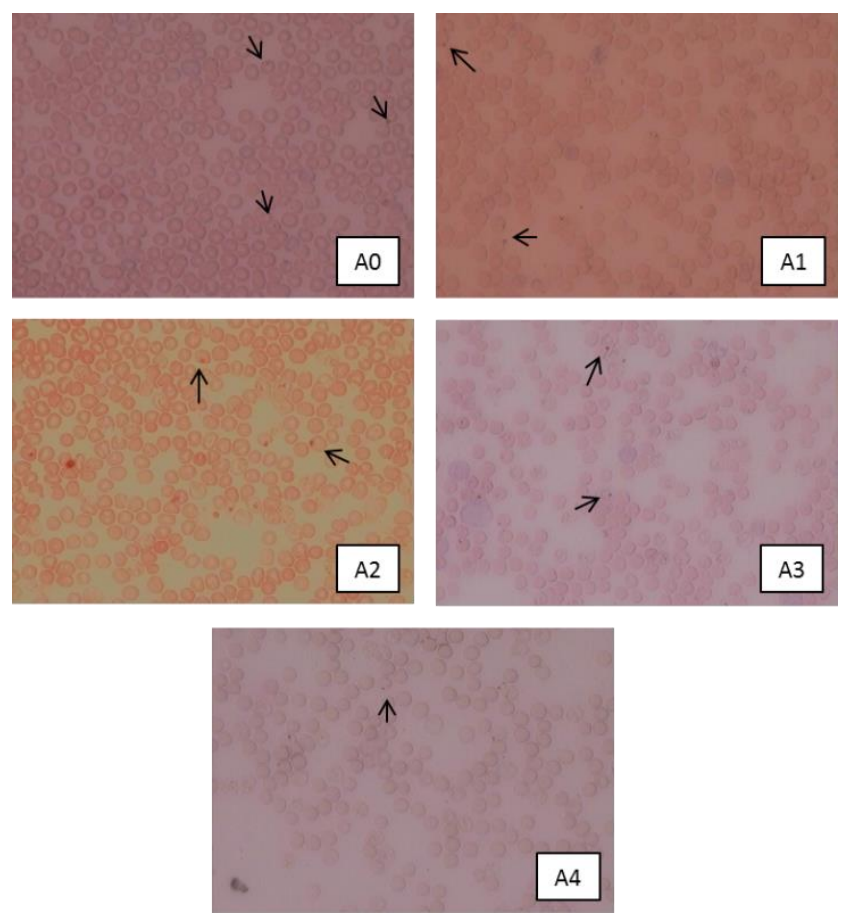

Fig 3. Picture of erythrocytes infected control (-) / no treatment on day 0 , day 1 , day 2 , day 3 , and day 4 , with a 400x magnification microscope observations.

The number of erythrocytes was infected by Plasmodium berghei increased along with increasing the treatment. The cells that infected with Plasmodium berghei will form a ring-shaped trophozoites. The erythrocytes that containing schizonts and tropozoit are have rough spots (indicated by arrows).

The treatment process can reduce the degree of parasitemia. Degree of parasitemia is used to determine the percent inhibition that resulting from any dose. The dose of effectiveness can be seen from the \% inhibition in each individual treatment group. \% Inhibition can be determined by the formula.

$$
\% \text { inhibition }=\frac{(\text { parasitemia of negative control }- \text { parasitemia of extract })}{\text { parasitemia of negative control }} \times 100 \%
$$


Table 6. The average value of percent and probit inhibition (Day-4)

\begin{tabular}{ccc}
\hline Treatment & \% Inhibition & Inhibition probit \\
\hline Dose $0,1 \mathrm{mg} / \mathrm{Kg} \mathrm{BB}$ & 55,22 & 5,15 \\
Dose $1 \mathrm{mg} / \mathrm{Kg} \mathrm{BB}$ & 72,866 & 5,74 \\
Dose $10 \mathrm{mg} / \mathrm{Kg} \mathrm{BB}$ & 87,342 & 6,182 \\
\hline
\end{tabular}

The dose effectivity of 50\% (ED50) was determined by percent of probit analyze from parasite inhibition during 4 days and that showed by linear regression analyze with Microsoft Office Excel program. The dose effectivity of 50\% (ED50) can not be determined because the average percent inhibition was above 50\% (55\% - 87\%).Pouplin et al. (2007), an extract is said to have the nature antiplasmodium when parasite inhibition may provide more than $30 \%$.It can be concluded that the combination of Calotropis gigantea radix and artemisin have a very good potential in inhibiting the growth of the parasite.

Inhibiton of Plasmodium berghei was due to the active compounds that can be contained from ethanol extract of Calotropis gigantea radix. The active compounds that can inhibit the growth of the parasite are steroids and tannins.

\section{CONCLUSION}

Conclusively, the combination of Calotropis gigantea radix and artemisin has a synergistic effect as an antimalarial drug. The result shows that combination of Calotropis gigantea radix extract and artemisin with dose $10 \mathrm{mg} / \mathrm{KgBW}$ has higher antimalarial activity than control positive (artemisin). The value of parasite inhibition is $55,2 \%$ for dose $0.1 \mathrm{mg} / \mathrm{KgBW} ; 72,8 \%$ for dose $1 \mathrm{mg} / \mathrm{KgBW} ; 87,3 \%$ for dose $10 \mathrm{mg} / \mathrm{KgBW}$ and $56,06 \mathrm{mg} / \mathrm{KgBW}$ for control positive (artemisin).

The active compounds that contained from ethanol extract of Calotropis gigantea radix with reagent test are steroids and tannins. It is also supported by the results using the TLC separation, the separation of steroid compounds that produce a reddish purple color with $\mathrm{Rf}$ $0.22 ; 0.26 ; 0.33 ; 0.38 ; 0.49$ and 0.6 and tannin produces purple-black color with Rf 0.62 .

\section{ACKNOWLEDGEMENT}

Our gratitude to Roihatul Muti'ah, M. Kes. Apt and Elok kamilah Hayati, M.Si of Pharmacy and Chemistry Departement, Islamic State Unversity of Maulana Malik Ibrahim Malang for providing the antimalaria protocol as well as puting us through and M. Basyar, S.Si of Biological Sciences Departement, Islamic State Unversity of Maulana Malik Ibrahim Malang, for helping the infected blood sample.

\section{REFERENCES}

[1] Fitriyani, A, dkk. 2011, Jurnal Majalah Obat Tradisional, 16(1), 34-42.

[2] Hafid F.A., Tyas W.M dan Widyawaruyanti A. 2011, J Indon Med Assoc, Vol.61. No 4.

[3] Kristanti A.N, Aminah N.S, Tanjung M, dan Kurniadi B. 2008. Buku Ajar Fitokimia. Surabaya: Airlangga University Pers. HX Chen; J Ying; H Chen; JL Huang; L Liao, Chromatographia, 2008, 6, 629-634.

[4] Mary J.M, Richard A.H, Pamela C.C, Bruce D.F, Michael C. 2000. Lippincott's Illustrated Reviews: Pharmacology. Lippincott Williams \& Wilkins, A Walter Kluwer Company, Philadelphia, USA, 349-353.

[5] Mudi, Y.S dan Bukar. A. 2011, Nigerian Society for Experimental Biology, Vol. 22. No. 1.P Vinas; N Balsalobre; MH Cordoba, Analytical Chimica Acta, 2006, 558, 11-15. 
[6] Newman, J.L., Mahretu, A., Shillington, K., and Stock, R. 2008. Africa. Microsoft Student 2008 [DVD]. Redmond, WA: Microsoft Coorperation.

[7] Pouplin, J.N., T.H., Tran, C., Dolecek, T.A., Phan, J., Farrar,P., Carron, B., Bodo, \& P., Grellier, 2007, Journal of ethnopharmacology, Vol. 109.A Gantverg; I Shishani; M Hoffman, Analytica Chimica Acta, 2003, 483, 125-135.

[8] Reveny,Julia (2011), Jurnal ILMU DASAR, Vol. 12 No. 1, Januari 2011: 6-12.

[9] Snow R.W, Guerra CA, Noor Am, Myint Hy, Hay SI. 2005, Nature 434 (7030): 214-7.

[10] WHO. 2010. Guidlines for The Treatment of Malaria. WHO Geneva. 